\title{
A Study on Culture of Goud Saraswat Brahmins - Special Reference on Uttar Kannada District
}

\author{
Jyoti G Nayak \\ Assistant professor, Department of History \\ Govt. First Grade College, Ankola Taluka, \\ Uttar Kannada Distict, Karnataka State, India
}

\begin{abstract}
Goud (also spelt as Gaud or Gawd) Saraswat Brahmins are a Hindu Brahmin community in India and a part of the larger Saraswat Brahmin community. They belong to the Pancha (five) Gauda Brahmana groups. They are popularly referred to as $\boldsymbol{G S B}$. They primarily speak Konkani as their mother tongue, but they tend to be fluent in language of the region they are resident in. This is evident with many of the temples of the Kuladevas being located in Goa. Over time, facing religious persecution by the Portuguese, they moved further south to coastal Karnataka and Kerala.The Konkani spoken by Karnataka Saraswats has borrowed loan words from Kannada while the Konkani spoken by Kerala Saraswats has borrowed loan words from Malayalam and speak with a Malayalam accent.GSBs celebrate almost all festivals in Hinduism, and follow the Hindu lunar calendar (Panchang in Konkani) that gives the days on which the fasts and festivals should be observed. The expecting mother also performs Ganapathi Pooja for a successful delivery and a healthy child. On the 6th day, a pen and lamp are kept near the child's head, symbolic of a wish for an intelligent child. When the child is 2 years, before he completes third year the "Jawla" (Child's first hair cut) ceremony is held. Like Barso, Munji, marriage and last rites, Jawla is one of the samskara's child will undergo being a GSB. GSB's arecremated according to Vedic rites, usually within a day of the individual's death. The death rites include a 13-day ceremony. This food can be eaten with rice or as such. Curd is a good combination with it. Due to disproportional sex ratio within the community, love marriages with other Indian communities are nowadays very common and cause a threat to the future of this community and their language.
\end{abstract}

Keywords: GSB, Culture, History

\section{INTRODUCTION}

In the ancient world and even in the modern society people usually form cohesive groups based on their language, culture and geographical location. These groups have a common ancestry and are led by chiefs of the families around which they gathered. Such communities are called tribes. There are innumerable tribes in this world. The Indian continent is not different from the rest of the world as far as tribes and the rivalries between them are concerned.

It seems there are two kinds of tribes in the Indian continent, the tribes and castes. The tribes are still in the forests and hills and not really part of the modern society. Castes have been living in the villages and cities since ancient times and are civilized. In the Indian Continent, a caste means a modern civilized tribe or clan or group of people that have marital relationship among them. Some castes are further divided into subcastes. Matrimonial relationship among subcastes is not acceptable due to differences in religious and cultural practices. It is important to note that the caste or tribe is blood-related and genetic, and hence hereditary. So, one has to be born into a caste or tribe to belong to that tribe or caste. Again, this is not unique to India. These ancient tribal traditions are slowly disappearing in this modern age. One among such communities in the Indian continent is the Brahmin caste. For consistency in this article, Brahmins are referred to as a caste.

\section{History}

Saraswat muni (who was a devotee of Goddess Saraswati) once needed disciples to spread his teachings and knowledge to the world. However, he could not get students who were capable of the task. So he prayed to Goddess Saraswati to help him. Pleased with his devotion the Goddess gave him fourteen sons. Each of them had a name and the same is used by his descendents as their surname. 
The sons had characteristics according to their names. They were taught by the sage and sent around the world with certain objectives.

The Saraswat Brahmins are mentioned in the Vedas, the Ramayana, the Mahabharata, the Bhagavata and even the Bhavisyottara Purana. They may have come from Central Asia and Southern Germany to the Indian sub-continent through the Hindu-Kush mountains and the Khyber pass to south in about 2000-1500 BC or they were indigenous. The meaning of 'Saraswat' has more than one origin. One refers to 'offspring of Saraswati the goddess of learning applied usually to learned and scholarly people. It may denote the residents of Saraswati river basin. The Brahmins of this region who are referred to as 'Saraswats' in Mahabharata and Puranas were learned in Vedic lore. They concentrated on studying subjects like astronomy, metaphysics, medicine and allied subjects and disseminating knowledge. To trace the Gaud Saraswat Brahmins' ancestry from Kashmir to Goa, story of famous seer "Saraswata" is considered: When there was a famine in north India, he continued to recite Vedic texts by consuming fish.

Due to geo-morphosis in the Himalayas, the Saraswati began to dry up and the Saraswats were forced to migrate to greener pastures. Some went to Kashmir in the north, others went eastward. Few made their way to the Konkan and Goa. These came to be recognised as Goud Saraswatsor Dakshinatya Saraswats, to distinguish them from other Saraswat groups of the north.

The new immigrants were called 'Goud' because they were followers of Monism or Advaita as preached by Shri Goudapadacharya, who was guru of Shri Govinda Padacharya whose direct disciple was the great Shri Shankaracharya, who resurrected Hinduismor Vedic religion in India. Shri Gaudapadacharya Mutt, first mutt of Saraswats dedicated to the memory of Goudapadacharya was established in Keloshi (Quellosim) in Goa in the 8th century AD. He later moved to Kaivalyapura or Kavale in Goa as the mutt at Keloshi was destroyed in 1564 AD by the Portuguese rulers. To this day, the swamis of Kavale math are known as Goudapadacharyas. Kavale Math is the Goud Saraswat community's Adimath (first math) and three main sub-sects of Dakshinatya Saraswats - Sashtikar (Dorke including Bardeshkars like Divkar), Shenvis (Karbharis), and Chitrapur Saraswats (Bhanaps) - were known as Goud Saraswats or Konkani Brahmins until 300 years ago. Other Saraswat subsects include Pednekars, Rajapur Saraswat Brahmins Balavalikars and kudaldeshkars. In the 13th century, Dwaita (Vaishnava) philosophy advocated by Madhvacharya became popular and many Saraswats adopted Vaishnavism. They continued to worship the deities they brought with them from the north. These were 'Mahan Girish' or Mangueshi, Shakti or Shantadurga, Vishnu, Ganesh and Surya. They form the 'Panchayatan' or five deities, sacred to all Saraswats.

Goud Saraswats were in all the kingdoms of the western coast under different dynasties right from 6th century A.D. Kadamba, Rashtrakuta, Hoysala, Chalukya Shilahara and Vijayanagarakings had given important posts to Saraswats. There were admirals, treasurers, ambassadors, army chiefs and foreign language interpreters among them. They were famous traders, who conducted maritime trade with Eastern and Western countries of the contemporary world. The spoken language of Saraswats is Konkani.

The Portuguese traders were followed by Christian missionaries. Forcible conversions began to take place under the Portuguese Royal Patronage in 1560. Most of the Saraswat families left Goa with their family deities, risking life and limb. They settled in the adjoining Hindu principalities. New temples came up in the coastal districts of Karnataka for Saraswat deities. As time passed, the idols were taken back to newly constructed temples in Goa. They are not in the original ancient spots, where churches were built, destroying earlier temples. Many people migrated to Kerala and built temples mainly dedicated to Vishnu and his avatars. The first Vaishnava Saraswat Math of Gokarna Math lineage was established in the year 1475 in Varanasi. The origin of Gokarna Math comes from the lineage of Sri Palimar Math, one of the eight Maths established by Sripad Madhwacharya in Udupi. Kashi Math at Kochi came up in 1560 A.D. All the Vaishnav Saraswats (Madhwa) are Kulavis (followers) of either Kashi Math or Gokarna Math. 'Smarth' Saraswats owe allegiance to either Kavale Math or Chitrapur Math.

Saraswats continued to hold important posts under Keladi or Nagar rulers. Many families who emigrated from Goa settled down in smaller towns and villages in Shimoga, South and North Kanara districts. Saraswats were the first beneficiaries of English education introduced in 1840. 


\section{GeOgraphical Location}

Brahmins are Vedik people. The Vedas describe the landscape of northern India, Pakistan and Afghanistan. Over and over the Vedas mention a mighty river called the Sarasvati where Brahmin communities flourished, where the Indus Valley civilization flourished and dispersed when the Saraswati river dried up around 1900 BCE. Long before, during the Ramayana period Brahmins migrated to Dandakaranya (Dandaka Forest) in the south with Viswamitra, the author of several hymns in Rigveda including Gayatri mantra, and practiced Vedik religon performing yajnas under the protection of Lord Rama and Lakshmana. Long before Rama went south, Agastya, a prominent Brahmin sage and writer of several hymns of Rigveda, crossed Vindhyas and established Vedik religion in south India. Sage Agastya appeared to Rama when he was despondent at the impending war with Ravana and instructed him in the use of Aditya Hridayam, a hymn praising the Sun God. Brahmins have been migrating to various regions within the Indian Continent since time immemorial and recently to other continents as well.

GSB means Gaud/Goud Saraswat Brahmin. Some use Gowda instead of Gaud/Gouda but it is wrong according to me. Gaud/Gouda means North India whereas Gowda is used by Vokkaligas (a caste of landowning peasants in South India).When the Saraswats came to the South from Punjab, Kashmir, UP and Bihar-Bengal, they prefixed Gaud/Goud to distinguish themselves as NorthIndian brahmins.

\section{Meaning of "Brahmin"}

The word Brahmin means many things to many people resulting in confusion. One of the reasons for this confusion is Sanskrit language. Many words in Sanskrit have many meanings. Depending upon the context one has to take the meaning of the word. The word Brahmana (hereinafter "Brahmin") means the God, one who knows God, one who has the knowledge of God, one who has the knowledge of Vedas, an intellectual, a priest, a teacher, a professor, a person belonging to Brahmin caste, a superior person, a text related to Vedas, and so on. Accordingly, priests in a mosque, church, a synagogue, a gurudwara etc. are all Brahmins because they are all, obviously, priests. They are also Brahmins because they are supposed to have the knowledge of God. They are also Brahmins because they are intellectuals. However, none of them are God and at least a couple of them would consider it blesphemous to say so. They may not have the knowledge of the Vedas and they may not belong to the Brahmin caste. And certainly, they are not the texts related to Vedas. To add to this confusion there are Boston Brahmins who are Americans and have nothing to do with the Vedas or vegetarianism. They are not even remotely related to the Indian Continent.

There are hundreds of religions, practices, traditions, castes, tribes etc. dubbed as Hinduism. One among those religions is the Brahminism practiced by the Brahmin caste. Brahmins have distinct traditions, culture and religion and follow certain principles and practices. This religion may also be called Sanatana (ancient) Dharma or Vedic religion. However, there is a lot of confusion as to the definition of Hinduism, which encompasses everything indigenous to the Indian Continent, e.g., some groups of Indians like Busddhists, Jains, Sikhs, dalit Christians, Muslims, and people like Iliah Kanche, a Kuruma Christian, confuse Brahminism with Hinduism (Indigenous Religions of Indian Continent). Iliah Kanche declares that he is not a Hindu, because he does not follow any of the principles of Brahmins such as vegetarianism etc. However, Brahminism is only one of the many religions of India that are collectively called Hinduism. Yet, almost all other Indian (Hindu) religions also respect the Vedas because they are essentially the human heritage and the most ancient texts. The Rig Veda was declared by UNESCO as part of the world heritage.

Most of the practicing Brahmins adhere to the principles such as acceptance of the Vedas with reverence; recognition of the fact that the means or ways to salvation and realization of the truth are diverse; God is one, but has innumerable names and forms to chant and worship due to our varied perceptions, cultures and languages; that a Brahmin works for the welfare of the entire society and so on. Daily practices of Brahmins include sandhyavandana (prayers to Gayatri and Sun God), prayer to ishtadaiva or ilavelpu (personal God), yoga, non-violence, vegetarianism etc. Everything in the daily life of a Brahmin is a ritual. However, special rituals include marriage, ritual conception and consummation of the wedding, rituals of childbirth, naming ceremony, first feeding ceremony, the child's first tonsure, upanayana (the sacred-thread ceremony - initiation into vedic learning and ritual), ritual baths, cremation rituals, shraaddha, etc. All of these rituals are very important for a practicing Brahmin. 
The Vedas are the primary source of knowledge for all Brahmin traditions, both orthodox \& heterodox. All religions of Brahmins and all traditions, in one way or other, take inspiration from the Vedas. Traditional Brahmin accepts Vedas as apaurusheyam (not man-made), but revealed truths and of eternal validity or relevance and hence the Vedas are considered Srutis that which have been heard and are the paramount source of Brahmin traditions and is believed to be divine. These Srutis include not only the four Vedas (the Rigveda, the Yajurveda, the Samaveda and the Atharvaveda), but also their respective Brahmanas. Brahmins also give tremendous importance to purity of body and mind and hence attach importance to ritual baths and cleanliness.

\section{GSB}

The term GSB is a very new ameliorative term. There were many castes in Goa like Shenvi, bardeskar, kutthalkar, sashtikar, shenaipaki, pednekar etc, used different titles and never inter-dined or inter married. Some were called bamans.it was some 150 years or before that the term Saraswat was used and the Sahyadrikhanda was edited and story about them were written in it later the term Gowda was added and extensive literature was created. Nowhere in history of goa or any copper plates, stone inscriptions mention the name Gowd saraswats, the sahyadrikhanda which mentions the Parashurama story is very recent.Same is the case with the shets, who were also divided into 3 sub-castes before and it was only some 300 years ago they acquired the name daivajna, (but its also said that it was given to them in 16th century by Sri Vadiraja teertha Swami when some of them adopted madhwa religion, which later was used by all) before that , since 4th century AD to 16th century they are mentioned only as sreshthi and sethi in copper plates and communidade records in halekannada. Same is the case with the GSBs which is a pretty new term. Even the Vanis started claiming to be Vaishyas, when they are mentioned as banijagas in copper plates, and known as Vanis only. But yes, the two groups shenvis and the shets seem to have been sanskritised at an very early date in history moreover many of them(though not all) might have descended from the vedic people who were again heterogeneous. They might even have diverse origins who were united at a very later stage.

There are more chances of all these castes who now constitute the GSB might have intermingled during Goa inquisition,in either old conquests, other parts in konkan, karnataka, maharashtra etc. which eventually led to inter-dining and then intermarriage giving rise to what we call now Saraswats.

According to the mythological chronicle Sahyadrikhanda of the Skanda Purana, ninety-six Brahmin families belonging to ten gotrasmigrated to Goa from western India. Even if Parashurama is considered as a historical figure, the regionalisation of Brahmins had not taken place during his era and he had brought only Brahmins and not specifically Saraswat Brahmins. According to Bhau Daji and Dharmananda Damodar Kosambi, there is no connection between Parashurama and the migration of the Brahmins. The Sahyadrikhanda is a later inclusion in the original Sanskrit Skanda Purana, not a part of the original Sanskrit text. The Parashurama legend serves as a symbol of the Sanskritisation that Goan culture experienced with the advent of Brahminical religion to the region. This was achieved to a certain extent through the agency of the Saraswat Brahmins who had migrated to Goa who sought to establish their hegemony.

Sahyadrikhanda mentions the original home of Saraswats as Tirhut. The section in which the Tirhut is mentioned has been tentatively dated to 1400 CE. A writer on the basis of the genealogy and chronology of Puranic sages has mentioned that Aryans reached Goa around 2500 BCE. This is based on a preconceived notion that Aryans and Saraswats were identical. Elsewhere in the same work the author has argued that Parashurama had brought only Brahmins and not specifically Saraswat Brahmins. Therefore, equating Aryans and Saraswats seems to be far-fetched. There is no agreement among scholars about the original home of Saraswats. The name by which these Brahmins have been designated clearly indicates that the river Saraswati had played an important role in their life. Even after the disappearance of the river, the Brahmins who had once inhabited the banks of river Saraswati retained the name of the region. There are evidences in history about the migration of the population from one region to another regions account of foreign invasions and sudden climatic changes. Recent researches in archaeology have shown that the Saraswati river dried up before 1000 BCE. For the study of the migration of the Saraswats to Konkan and Deccan, the linguistics provides corroborative evidence. The main line of Indo-Aryan linguistic expansion began much before $500 \mathrm{BCE}$. 
Reference to Saraswat names are found in Shilaharas well as Kadamba copper plate inscriptions. The inscriptions found in Goa bear testimony to arrival of Brahmin families in the Konkan region. Sahyadrikhanda and Mangesh Mahatmya allude to migrations of Saraswat brahmins, constituting sixty-six families, who settled in eight villages of Goa. There were regional variations among the Saraswats, such as those among Bardeskars, Pednekars and Sastikars. The Konkana mahatmya, from the 17th century CE, deals with the internal rivalry of the Saraswats and strained relations between these groups. The GSB ancestors identified themselves as of the Saraswat section of the northern Gaud division, in contrast to their Maharashtra and Karnataka Brahman neighbors of the southern division. Those neighbors questioned the GSB's competence to perform all six duties (shatkarma) reserved to brahmans. It was said that the GSB could study the vedas, but not teach them; give alms to brahmans, but not accept them; and have sacrifices performed, but not perform them. There is no substantial evidence to bear out these assertions. They seem mainly to have rested upon a general suspicion of outsiders, and perhaps the inclusion of fish in the GSB diet. In spite of such vilification, Saraswats continued to prosper in Maharashtra. Furthermore, the Dravida Brahmins, in the scramble for posts and positions, developed antipathy towards the Gauda Brahmins, and this rivalry had its manifestation in various places. (In Maharashtra, the Saraswats were looked down upon and were described as not Shatkarmis but only Trikarmis. But the Bombay High Court during the 19th century decreed that they were qualified to perform all the six karmas).

Hence besides their sacerdotal duties, they took up administrative vocations under the ruling dynasties. Therefore, they gradually established themselves in the landowning class and also as traders. After settling down in Karnataka and Goa in about 800 CE Saraswats may have taken about a century to acquire patronage from the Shilaharas and the Kadambas of Goa. Many Saraswats left Goa after the invasion of Malik Kafur to the neighbouring regions and during the period of religious persecution of the Portuguese also Saraswats migrated to Uttar Kannada, Dakshina Kannada and North Konkan. The Saraswat Brahmins particularly served as village Kulkarnis, financiers, tax farmers, merchants in the intra-Asian trade, and diplomats. Many sources of government income in Goa, Konkan and elsewhere, including taxes on commodities and customs duties, remained in their hands.

In Kalhana's Rajatarangini (12th century CE), the Saraswats are mentioned as one of the five Pancha Gauda Brahmin communities residing to the north of the Vindhyas.

\section{Population And Distribution}

The Goud Saraswat Brahmins, in the course of their migration settled on a small strip on the west coast of India in the present day Goa. This is evident with many of the temples of the Kuladevas being located in Goa. Over time, facing religious persecution by the Portuguese, they moved further south to coastal Karnataka and Kerala. They are found all over the west coast of India ranging from Goa, Maharashtra, Karnataka and Kerala, most of them having their deities in Goa. Gaud Saraswat Brahmins are categorised by Last name (indicating profession), Gotra (lineage) or Math (spiritual guru).

\section{LANGUAGES OF SARASWATS}

As per my knowledge Konkani and Marathi are spoken in Saraswat(GSB) homes and not Kannada and Malyalam,these languages are spoken outside the house.so they cannot be their mother tongues.

Goud Saraswat Brahmins speak primararily Konkani as their mother tongue. The Konkani they speak is slightly different from the Konkani spoken by other communities such as the Catholics, Navayaths, Siddis etc. The Konkani spoken by Goan Saraswats, Karnataka Saraswats and Kerala Saraswats is also different. The Konkani spoken by Karnataka Saraswats has borrowed loan words from Kannada while the Konkani spoken by Kerala Saraswats has borrowed loan words from Malayalam and speak with a Malayalam accent. This was due to several centuries of domicile by the Saraswats in these areas.

However the usage of the language by the community is on the decline due to the following factors-

$>$ In Goa, the Portuguese discouraged the usage of Konkani in Goa and imposed Portuguese language as official, leading to its decline in Goa

> In Maharashtra, Karnataka and Kerala, the usage of Marathi, Kannada and Malayalam respectively was preferred in place of Konkani. 
$>$ The need for usage of English and Hindi languages has also contributed to this decline.

\section{Festivals}

GSBs celebrate almost all festivals in Hinduism, and follow the Hindu lunar calendar (Panchang in Konkani) that gives the days on which the fasts and festivals should be observed.

GSB's celebrate almost all festivals in Hinduism. They follow the Hindu Lunar calendar, almanac to be specific which is known as punching in Konkani that gives the days on which the fast and festivals should be observed.

\section{Rituals}

During the eighth month of pregnancy, a woman moves to her mother's house, especially during the birth of her first child. The expecting mother also performs Ganapathi Pooja for a successful delivery and a healthy child. On the 6th day, a pen and lamp are kept near the child's head, symbolic of a wish for an intelligent child. On the 12th day, the naming and cradling ceremony is performed wherein the paternal grandmother whispers the child's name into his/her ear and a horoscope is cast. When the child turns three months old, they are taken to the temple, and thereafter the child goes to the father's abode.

\section{BARSO}

On eleventh day of child birth barso is held. If done with homa (holy fire - havan), it is called Barso homa. Childs ears are pierced, child is named and cradled on this day.

\section{JAWLA}

When the child is 2 years, before he completes third year the "Jawla" (Child's first hair cut) ceremony is held. Like Barso, Munji, marriage and last rites, Jawla is one of the samskara's child will undergo being a GSB.

Munji ( Upanayanam or Tread Ceremony) When the male child turns 8 years old, theMunji (Konkani word for Upanayanam) is performed. In this ceremony, the jannuvey or the sacred thread is placed on the left shoulder of the child. From that day on, he becomes an official member of his caste, and is called a dwija (translated in English as "twice-born"). In ancient times, the boy was sent to gurukula to learn Vedas and scriptures. The boy was expected to practice extreme discipline during this period known as brahmacharya. He was expected to lead a celibate life, living on alms, and surviving on selected vegetarian saatvic food and observing considerable austerity in behaviour and deeds. On completion of the thread ceremony the boy will be eligible to go to gurukula which is available in 4 places across India i.e. Kashi Mutt Gurukula / Patashala at Mangalore and Mulki, Gokarn Mutt Gurukula at Partagali and Kavale Mutt Gurukula at Goa. Priests will be studying at anyone of these gurukulas. Normal members of GSB Community study here. The thread is changed every year in a festival known as Sutta Punav in the Hindu month of Shravan and under different circumstances like Suthige etc.

Some of the main rituals in a GSB munji are Devatha Prarthana, Ganapathi Puja, Udada Murthu, Matrubhojan, Yajnopavita Dharana, Brahmachari Agnikaryam, gayitri Upadesha, Danda Dharana, Matrabiksha etc.

\section{Marriage}

A typical GSB marriage consists of the following events - Varan Appoche, Nandi, Nishchaithambul, Yedur Kansnani, Urdha Murthu, KashiYatra, Lagna, HavanPurnavati, Chautanan, TulsiPuja and Mandal Virajan.

\section{DEATH CEREMONIES}

The other extremely important rituals for the GSB's are the death ceremonies. All GSB's arecremated according to Vedic rites, usually within a day of the individual's death. The death rites include a 13-day ceremony. The ashes of the departed are immersed at a confluence of two rivers (sangam) or the sea. Like all other Hindus, the preference is for the ashes to be immersed in the Ganga river or river Godavari river or river Kaveri. There is also a yearly shraddha that needs to be performed. These rituals are expected to be performed only by male descendants (preferably the eldest son) of the deceased. 


\section{Pathrodo}

Pathrodo is a tasty vegetarian dish made from colocasia leaves is very special for GSBs. This food can be eaten with rice or as such. Curd is a good combination with it. Half cooked colocasia leaves can irritate your throat. Lack of colocasia leaves due to urbanization is causing threat to the existence of this special dish.

\section{MODERN GENERATION AND THEIR LIFESTYLE}

The modern GSBs are often regarded as well educated, fair and handsome by other South Indians. Their lifestyle is very different from other south Indians and they even mingle better with non-south Indians. They are multi-lingual, they can handle multiple Indian languages and also English. Due to disproportional sex ratio within the community, love marriages with other Indian communities are nowadays very common and cause a threat to the future of this community and their language.

\section{FACtS about Gaud SARASWat Brahmins}

GSBs are a business community - financially well off to a certain extent and influential. FYI The GSB seva mandal Ganpati organization of Mumbai belongs to GSBs and is one of India's richest organizations. Now, why is this lesser known fact - because Indians are so much preoccupied with Marwaris, Sindhis, and Gujaratis as having 'business community' label, that all other Indians are kind of sidelined.

Not exactly about GSBs, but I always find it weird when people show extremely low general knowledge about the very definition of Konkan, which is the home territory of GSBs. Ask any ethnic Marathi, and he will invariably say that Konkan means just the coastal belt of Maharashtra. They simply don't know that Konkan means everything (coastline) between Mumbai and Northern Kerala. They also don't know that the native language of Goa is Konkani.

About Konkanis in general - a lesser known fact - they belong to multiple religions - Hinduism, Christianity, and Islam. Despite this, what binds them together is the Konkani language.

Lesser known fact about GSBs is that - Vittal Malya, Sachin Tendulkar, Deepika Padukone, Vijay Mallya, Nandan Nilekani, are all GSBs..

\section{REFERENCES}

[1] Vayaupuranamu in "Ashtadasapuranamulu," by Venkataramasastri Kompella, Rohini Publications, Rajamandri, pp. 308-309.

[2] In Sanskrit, gotram means family, race, lineage, a mountain, a cow-pen and so on!

[3] "Andhra Viprula Gotramulu, Indla Perlu, Sakhalu," by Emmesroy Sastri, Gollapudi Veeraswami Son, Sri Seetarama Book Depot, Rajamandri.

[4] History and Culture of Andhra Pradesh, Rao PR, pp.viii and 8-22

[5] History of India, Herman Kulke and Dietmar Rothermund, p. 102

[6] History of India, Herman Kulke and Dietmar Rothermund, p. 104

[7] History and Culture of Andhra Pradesh, Rao PR, pp.viii and 8-22

[8] "Hindu Castes and Sects," Jogendranath Bhattacharya, 1896. 